\title{
Geospatial Analysis of Rural Weekly Markets: A Case Study of Bemetara District of Chhattisgarh, India
}

\author{
Ms. Tisha Dey ${ }^{1}$, Dr. A.K Pathak ${ }^{2}$, Dr. N.K Baghmar ${ }^{3}$ \\ ${ }^{1}$ (Department of Geography, Pt. Ravishankar Shukla University, Raipur, Chhattisgarh, India) \\ ${ }^{2}$ (Department of Sci. \& Tech., Chhattisgarh Space Application Centre, Raipur, India) \\ ${ }^{3}$ (Department of Geography, Pt. Ravishankar Shukla University, Raipur, Chhattisgarh, India)
}

\begin{abstract}
Markets are the most extensive system for exchange and play a dynamic role not only in rural socioeconomic development but also carry out the significant role in the regional level of development. The role of markets in rural development planning is very essential. Country like India, the weekly markets are the farmers first contact point with the marketing channels and considered as the nerve centers of economic, social and cultural activities of the rural life. The growth of new market centers always follows the development of agriculture, industries and transportation. Present research work is case study on how geospatial technology helps in rural market analysis. Here Remote Sensing, GIS and GPS all played important role in analysis. All hardcopy data has transferred into GIS platform for various types of analysis. The study area has total 108 rural weekly markets which serve total 700 villages and 721192 rural population of Bemetara district. Nearest Neighbour Analysis has done to study spatial pattern of weekly markets. Based on periodicity markets are also analyzed and un-served area has identified. GIS as a powerful tool helps in various types of overlay analysis which produce fruitful result which is essential for planning and decision making.
\end{abstract}

Keywords - Geography, Geospatial, Markets, Planning, Rural

\section{INTRODUCTION}

Geography is a discipline achieving much importance not only in the discipline itself but also in multi discipline point of view. It interrelate many branches which are either directly or indirectly related to the socio-economic activities of a common man. Marketing is a fundamental part of economic geography. The necessity of marketing geography was first pointed out by William Applebaum an American geographer. Markets are the most extensive system for exchange and play a dynamic role not only in rural socio-economic development but also carry out the significant role in the regional level of development. The role of markets in rural development planning is very essential. Country like India, the periodic markets are the farmers first contact point with the marketing channels and considered as the nerve centers of economic, social and cultural activities of the rural life. The growth of new market centers always follows the development of agriculture, industries and transportation. The most effective work has been done by Dixit (1979), highlighted the market centers and their spatial development in the umland of Kanpur. Wanmali (1981) has point out that still the weekly markets can be accepted as central places, as they are 'fixed' in space but not fixed' in time. Hugar (1982) observed the role of weekly markets in the development of rural areas of Gadak taluk. The role of markets in rural development planning is the need of the hour to study. Therefore, the academicians, planners and social scientists use these periodic markets in formulating their regional development strategies as nodes or hearts of diffusion of development impulses. These nodes are created functional landscape features which have been imposed upon the evolved periodic markers Mukerji (1988). Saxena (2004) analysed the role of market towns in regional development of Rajasthan and focused on rural planning. Mulimani (2014) has attempted to study the role of periodic markets in rural development. According to him the spatial distribution of periodic markets and their functions are responsible for spatial interaction.

The development of market centers always follows the development of agriculture, transportation and industries. Market villages are economically most feasible and represent the regional pattern of development because market villages provide trade and commerce service to the region, act as nodal centre for transportation and serve as a growth centre by providing different services to the region. Thus, marketing system as well as social composition is always in a situation of change both in terms of space and time. Whatever change has occurred in the social composition is the result of numerous factors. Among them marketing is also one of the most important factors and it provides a chance of interaction between rural population and urban surroundings. As a result, the attempt has been made in the present paper to deal with the role of weekly markets in rural development of Bemetara district. It emphasizes mainly to raise the distributional characters of rural market in the study area. 
II. OBJECTIVES

- To study the spatial distribution of rural weekly markets

- To find out the served and un-served area of rural weekly markets

\section{STUDY AREA}

Study area has been chosen as a newly formed district of Chhattisgarh that is Bemetara district. Bemetra district has been bifurcated from Durg District in the year 2012. The main purpose of bifurcation and formation of new district is for decentralized planning and for effective planning and proper implementation of different government scheme. The study area lies between $21^{\circ} 20^{\prime} 79^{\prime \prime}$ to $22^{\circ} 1$ ' $24^{\prime \prime}$ latitude and $81^{\circ} 10^{\prime} 22^{\prime \prime}$ to $81^{\circ} 56^{\prime} 8^{\prime \prime}$ longitude. It covers a total geographical area of 2886.94 sq.km. Bemetara district is also known as 'Unhari District". It mainly comes under Chhattisgarh plain and it is agriculturally sound district. Important river flowing in the district is Sheonath river. As per 2011 census, total population of the district is 721192 . Density of population is 104 person/ sq.km. Literacy rate of the district is $71 \%$. Sex-ratio has been found is 1015 .

Bemetara district has been divided in two sub-division that is Bemetara and Saja. Total number of block is four namely, Bemetara, Berla, Nawagarh, Saja. Total number of Gram Panchayat in the district are 334 and total number of villages are 700. The district is divided into total 8 RI circles. Fig.1 shows the Location Map of Study area.

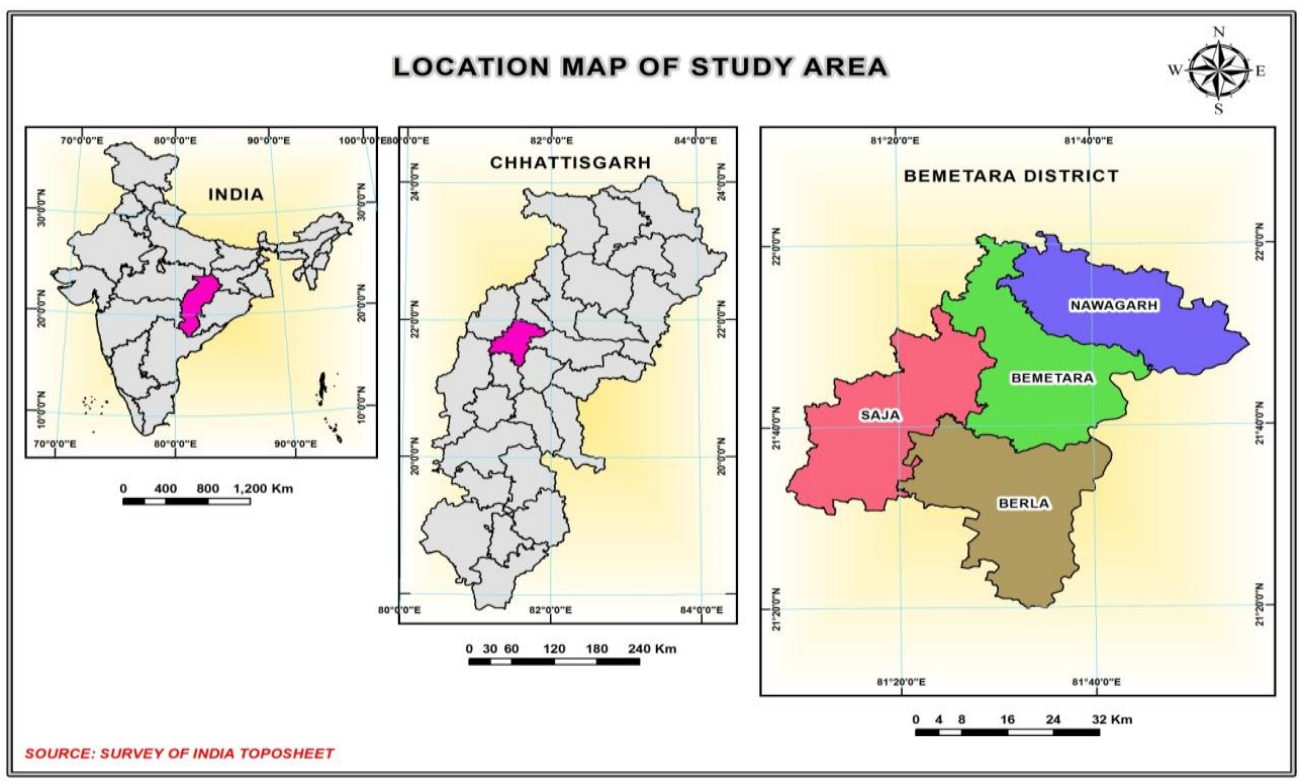

Figure 1 Location Map of Study Area

\section{DATASETS AND METHODOLOGY}

Present study is mainly based on two types of data primary and secondary. GPS locations of all weekly markets are considered as primary data. All hardcopy data regarding weekly markets are borrowed from concerned office. Village map has acquired from Land Record department. Census, 2011 data has used for rural population study.For geospatial analysis all hardcopy data regarding rural weekly market has entered into MS Excel format. With the help of GPS point location all data has brought into GIS platform and formed geospatial attribute database of rural weekly markets. Based on this geodatabase further different types of analysis has performed like nearest neighbor analysis, query analysis, proximity analysis etc. Village information has further linked with the market database in order to find served and un-served area. The Cartographic Method has employed and prepared the required maps and accordingly analysis has been done.

\section{RESULT AND DISCUSSIONS}

\subsection{Spatial Distribution of Rural Weekly Markets}

Location and distribution has always been considered as the fundamental step in all geographical analysis. Based on this, first of all rural weekly market geo-database has created in ArcGIS 10 with all attribute data along with all GPS points captured from field. Exact location of markets has placed over the village boundary layer. With these locations all other important layers like road, tehsil, river, etc. has overlaid on it for 
further analysis. All the market locations can also be overlaid on the satellite imagery in order to observe the ground condition. GIS play an important tool in study of rural markets. From this geo-database one can generate different types of maps based on attribute details. Fig.2 shows the database in ArcGIS 10 platform.

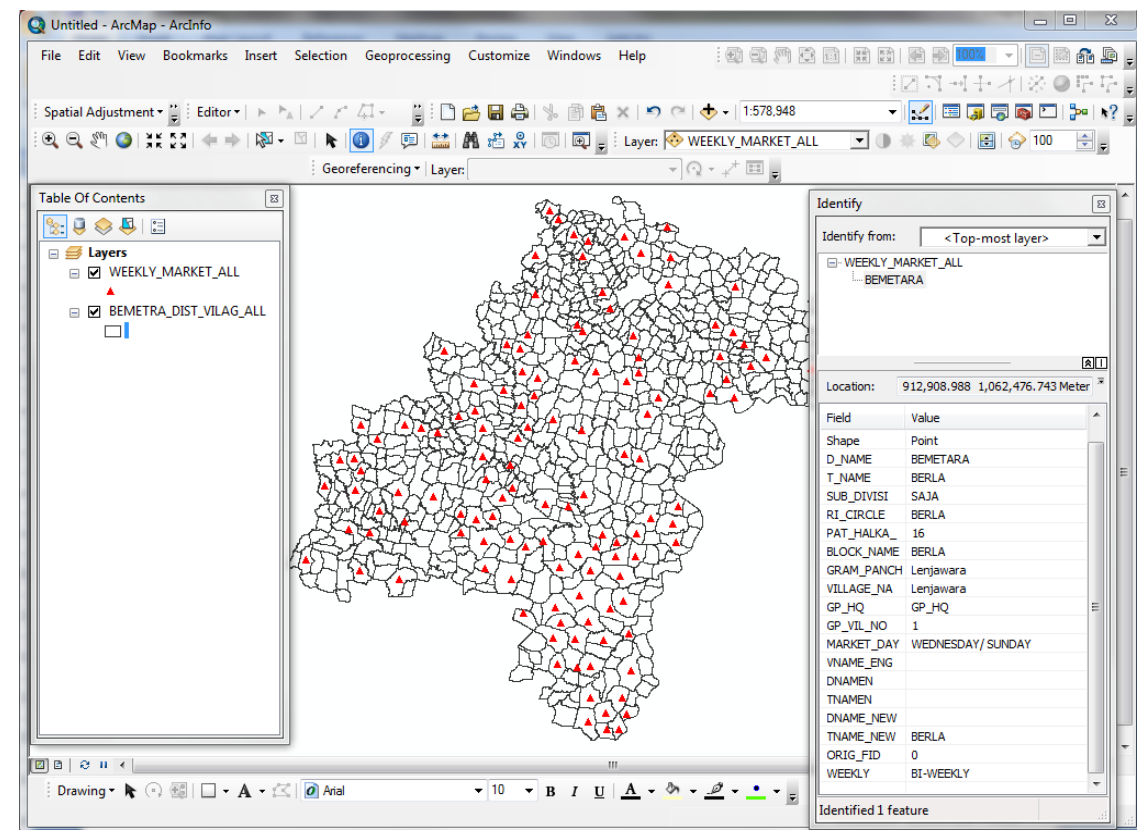

Figure 2 Geodatabase of Rural Weekly Market on ArcGIS 10

\subsection{Spatial Pattern of Rural Weekly Markets}

Spatial pattern is one of the essential factor in geography. The spatial distribution of market centres varies from block to block due to various factors like area, population, resources, transport network, etc. The study of the spatial pattern of rural market centre is an important aspect of study in geography. Nearest Neighbour Analysis technique has applied in order to study the distribution pattern of the rural market centres of Bemetara district. Table 1 shows the spatial pattern of rural market centre in study area.

Table 1 Bemetara District : Nearest Neighbour Statistics of Rural Market Centers

\begin{tabular}{|l|l|l|l|l|l|l|l|}
\hline S.No. & Name of Block & No. of Markets & Area in sq. $\mathbf{k m .}$ & $\mathbf{D} \overline{\mathbf{o}}$ & $\mathbf{D e}$ & Rn & Remarks \\
\hline 1. & Bemetara & 25 & 728.45 & 3.22 & 2.75 & 1.16 & Random \\
\hline 2. & Berla & 60 & 771.60 & 2.68 & 1.95 & 1.37 & Deviation from Random \\
\hline 3. & Nawagarh & 18 & 662.0 & 3.52 & 2.87 & 1.22 & Deviation from Random \\
\hline 4. & Saja & 35 & 740.1 & 3.21 & 2.27 & 1.40 & Deviation from Random \\
\hline \multicolumn{2}{|l}{ District Total } & $\mathbf{1 0 8}$ & $\mathbf{2 8 6 2 . 1 8}$ & 3.15 & 2.4 & 1.28 & Deviation from Random \\
\hline
\end{tabular}

Source: Computed by Researcher in GIS

The above table reveals the fact that almost all blocks are having tendency of deviation from random pattern of distribution of market centre. Only one block i.e. Bemetara showing random distribution of market centres observing value in $\mathrm{Rn}$ scale is 1.16 . Overall Bemetara district also shows the tendency of deviation from random with $\mathrm{Rn}$ value of 1.28 .

\subsection{Temporal Distribution of Rural weekly Market Centers}

The temporal aspect is also an essential dimension in market geography. Temporal distribution is as much as important like spatial distribution. The distribution of markets on temporal basis in geographic space is normally termed as temporal distribution. There are different factors which are responsible for selection of the market day for a particular place like proximity to other nearby markets, demand of goods, social and cultural aspects, etc. Except daily markets, there are some definite days in a week on which market reaches on its peak. Fig.2 shows the spatial distribution of frequency of rural market day during market week. In the entire Bemetara district, 108 markets are held at every week. The frequency of market based on day-wise has shown in Table 2. 
The table reveals that Thursday is the peak day in a week where maximum marketing takes place i.e. 26 markets. Sunday occupied last rank in market meeting in the study area.

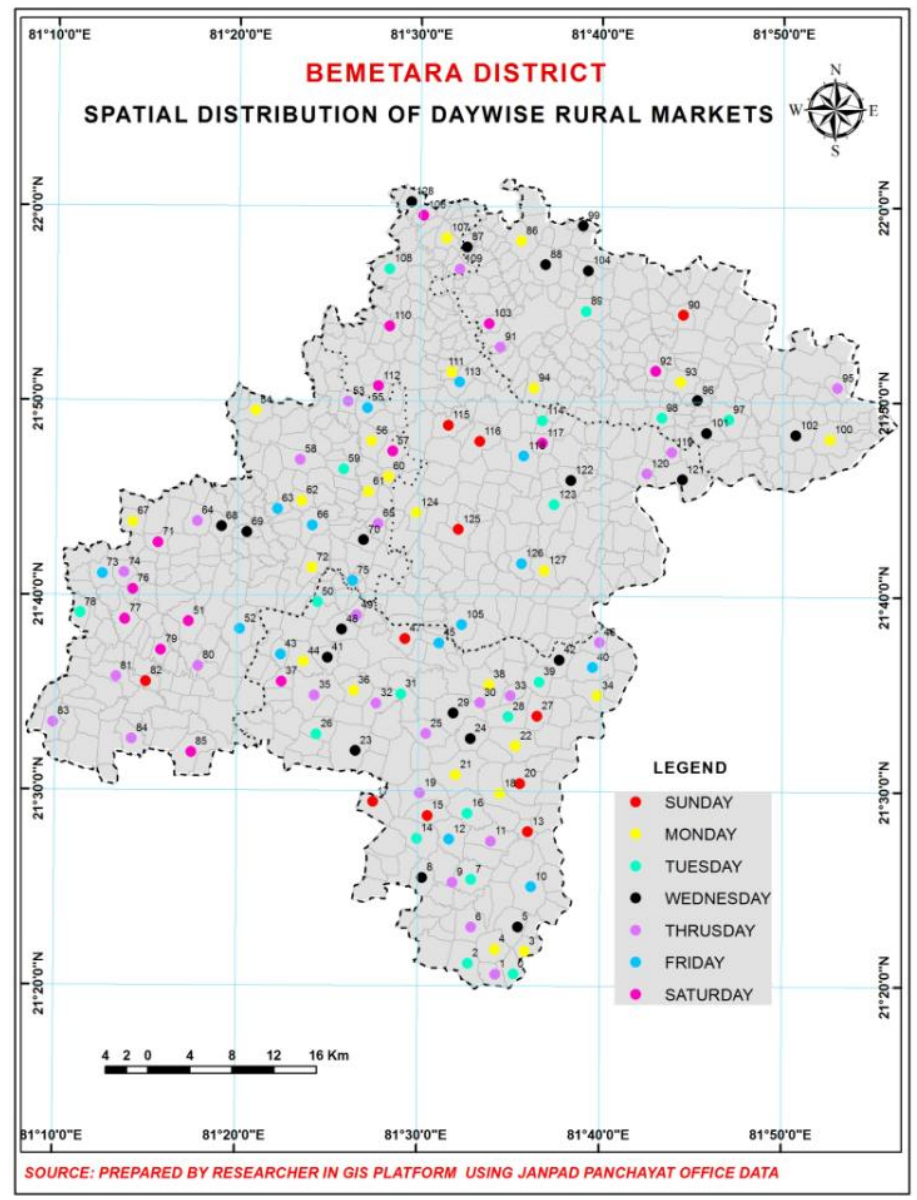

Figure 3 Spatial Distribution of Daywise Rural Markets

Table 2 Bemetara District: Day-wise Distribution of Market Centres

\begin{tabular}{|c|c|c|c|c|c|c|c|c|c|}
\hline \multirow{2}{*}{ S.No. } & \multirow{2}{*}{$\begin{array}{l}\text { Name of } \\
\text { Block }\end{array}$} & \multirow{2}{*}{$\begin{array}{l}\text { No. of } \\
\text { Market }\end{array}$} & \multicolumn{7}{|c|}{ Week Days } \\
\hline & & & Sunday & Monday & Tuesday & Wednesday & Thursday & Friday & Saturday \\
\hline 1. & Bemetara & 25 & 3 & 4 & 3 & 3 & 3 & 4 & 5 \\
\hline 2. & Berla & 30 & 9 & 9 & 10 & 8 & 12 & 5 & 3 \\
\hline 3. & Nawagarh & 18 & 2 & 4 & 3 & 7 & 2 & 1 & 4 \\
\hline 4. & Saja & 35 & 1 & 7 & 2 & 3 & 9 & 6 & 7 \\
\hline \multicolumn{2}{|c|}{ District Total } & 108 & 15 & 24 & 18 & 21 & 26 & 16 & 19 \\
\hline
\end{tabular}

Periodicity is an important factor of rural weekly markets. It has observed that system of market periodicity provides an adjustment with agricultural system. Only one marketing day in a seven day week means six other days of other agricultural activities and rural people get enough time for rest as well as four preparation for the next visit to market (Mulimani, 2006). The periodicity of market is a common feature of the periodic markets and it can vary from once, twice, thrice, etc. As per the study area is concerned, it has observed that, there is no tri-weekly market, shown in Table 3. Out 108 market centres of Bemetara district 93 markets are functioning in the study area once in a week. On the remaining days there is no market day. There is no daily market in the study area. Highest number of bi-weekly market has found in Berla block. Large number of weekly market has found in Saja block. 


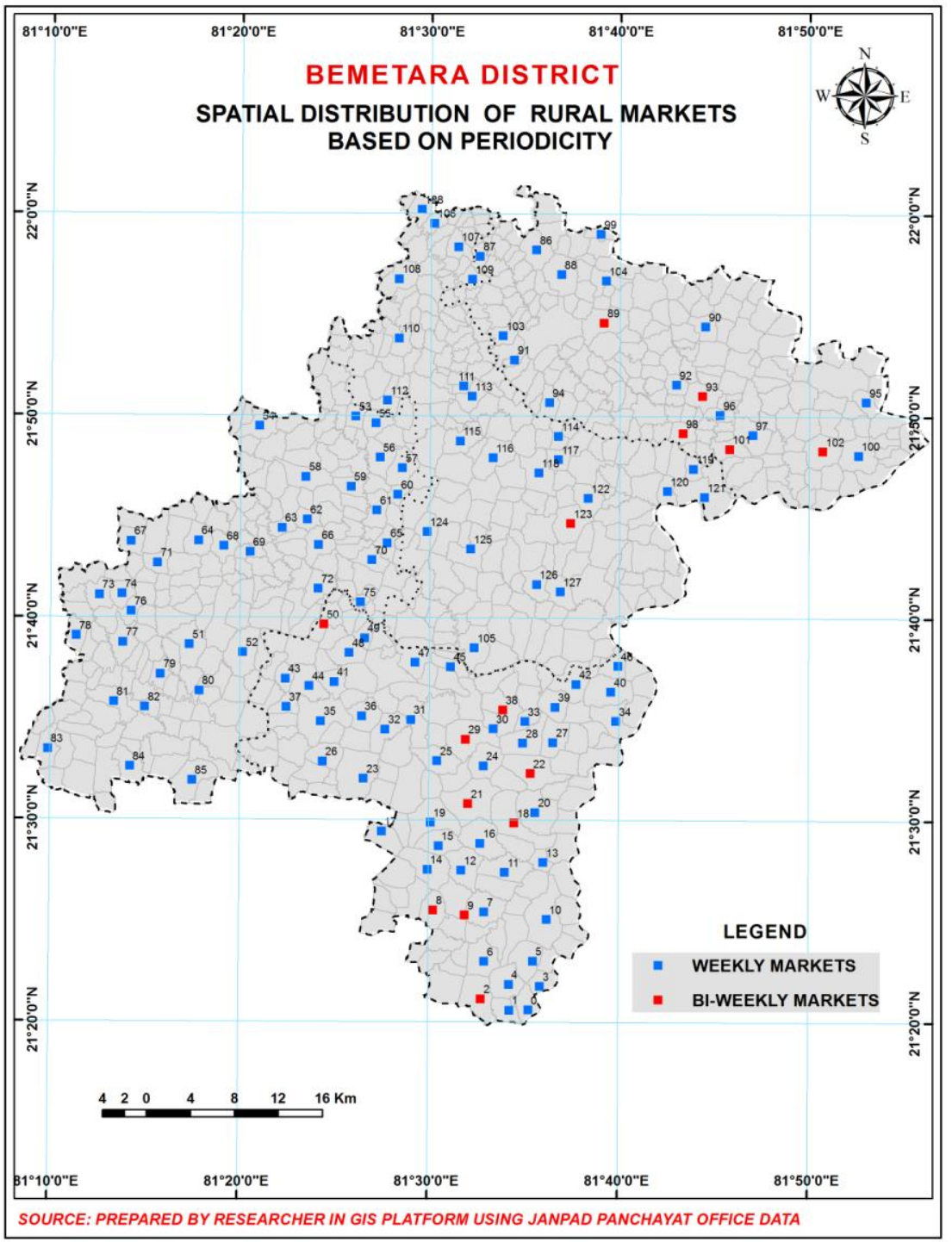

Figure 4 Spatial Distribution of Periodicity of Rural Markets

Table 3 Bemetara District: Market Periodicity

\begin{tabular}{|l|l|c|c|c|}
\hline S.No. & Name of Block & Total No. of Markets & No. of Weekly Market & No. of Bi-weekly Market \\
\hline 1. & Bemetara & 25 & 24 & 1 \\
\hline 2. & Berla & 30 & 21 & 9 \\
\hline 3. & Nawagarh & 18 & 13 & 5 \\
\hline 4. & Saja & 35 & 35 & 0 \\
\hline & District Total & $\mathbf{1 0 8}$ & $\mathbf{9 3}$ & $\mathbf{1 5}$ \\
\hline
\end{tabular}

Source: Computed by Researcher in GIS

\subsection{Distribution relationship of Rural Weekly Markets}

The block wise distribution of market centres in the Bemetara district mainly depends upon socioeconomic condition of the settlements. The district has $2886.24 \mathrm{sq}$. km. of total geographical area with four blocks consisting of 108 rural weekly markets unevenly distributed over study area. Berla block has highest number of rural weekly markets whereas Nawagarh block has the lowest number of markets. This type of difference mainly observed because of level of accessibility, socio-economic activities and location advantage of market centres. 
Table 4 Bemetara District: Market Centres Distributional Relationship

\begin{tabular}{|c|c|c|c|c|c|c|c|c|c|}
\hline \multirow[b]{2}{*}{$\begin{array}{l}\text { S.No } \\
\text { • }\end{array}$} & \multirow[b]{2}{*}{$\begin{array}{l}\text { Block } \\
\text { Name }\end{array}$} & \multirow[b]{2}{*}{$\begin{array}{l}\text { No. of } \\
\text { Market } \\
\text { Centres }\end{array}$} & \multirow[b]{2}{*}{$\begin{array}{l}\text { Area } \\
\text { (sq. } \\
\text { km.) }\end{array}$} & \multirow[b]{2}{*}{$\begin{array}{l}\text { No. of } \\
\text { Villages }\end{array}$} & \multirow[b]{2}{*}{$\begin{array}{l}\text { Total } \\
\text { Population }\end{array}$} & \multicolumn{4}{|c|}{ Percentage Share of Each Market in the District } \\
\hline & & & & & & Area \% & $\begin{array}{l}\text { Village } \\
\%\end{array}$ & Population \% & $\begin{array}{l}\text { Compos } \\
\text { ite } \\
\text { Index }\end{array}$ \\
\hline 1. & Bemetara & 25 & $\begin{array}{l}728.48 \\
(25.4)\end{array}$ & $\begin{array}{l}188 \\
(26.8)\end{array}$ & $\begin{array}{l}187088 \\
(25.99)\end{array}$ & 1.01 & 1.07 & 1.03 & 3.11 \\
\hline 2. & Berla & 60 & $\begin{array}{l}771.6 \\
(26.9) \\
\end{array}$ & $\begin{array}{l}137 \\
(19.51)\end{array}$ & $\begin{array}{l}182211 \\
(25.26) \\
\end{array}$ & 0.44 & 0.32 & 0.42 & 1.18 \\
\hline 3. & Nawagarh & 18 & $\begin{array}{l}622.0 \\
(21.73) \\
\end{array}$ & $\begin{array}{l}187 \\
(26.63) \\
\end{array}$ & $\begin{array}{l}179944 \\
(24.95)\end{array}$ & 1.20 & 1.47 & 1.38 & 4.05 \\
\hline 4. & Saja & 35 & $\begin{array}{l}740.1 \\
(25.8)\end{array}$ & $\begin{array}{l}190 \\
(27.06)\end{array}$ & $\begin{array}{l}171949 \\
(23.62)\end{array}$ & 0.73 & 0.77 & 0.73 & 2.23 \\
\hline \multicolumn{2}{|c|}{ District Total } & 108 & $\begin{array}{l}2862.18 \\
(100)\end{array}$ & $\begin{array}{l}702 \\
(100)\end{array}$ & $\begin{array}{l}721192 \\
(100)\end{array}$ & 3.38 & 3.63 & 3.56 & 10.57 \\
\hline & Average & & & & - & 0.84 & 0.90 & 0.89 & 2.64 \\
\hline
\end{tabular}

Source: Computed by Researcher in GIS

\section{Market Centres and Area}

Each and every market tends to serve a definite area around it. In the present study on an average each rural weekly market centre serves $0.84 \%$ area of the district shown in Table 4. Out of four blocks, two blocks namely Bemetara and Nawagarh served more than district average. In the remaining blocks, the transport facilities are satisfactory and agricultural activities are carried out and each market centre serves lesser percentage of area of the study area. Thus, farmers need more markets to sell their large quantity of agricultural products seasonally. Therefore, more number of market centres will come up in these blocks with enough number of banks and co-operative societies. Fig. 5 shows the market centres and area relationship of Bemetara district

Market Centres and Population

Every market centre serves a definite proportion of population in the area around it in each block. It is calculated that, shown in Table 4 on an average each market centres serves $0.89 \%$ of the district rural population. Out of four blocks two blocks namely Bemetara and Nawagarh represents higher percentage of rural population than the district average, whereas, rest of the two blocks each market centre serves less percentage of population than the district average. Fig. 5 shows the market centres and population relationship of the study area.

Market Centres and Number Of Villages

Every market centres serves different villages in different way. Table 4 indicates that, each market centre serves on an average $0.90 \%$ of villages of Bemetara district. The percentage shae of each market is more than that of the district average. The other blocks such as Berla and Saja have high concentration of market activities and allows the growth of many-many market centres and each rural market centre serve very limited number of village shown in Fig. 5.

Composite Index

The present study on rural market centres indicate the composite index in order to understand the combined effect of area, population and villages served by each rural market centre in order to understand the distribution relationship. Therefore, Composite Index Value has calculated and deviation from the average has drawn from the data.

The rural market centres of Bemetara and Nawagarh blocks serve many villages, area and population than other blocks of Bemetara district. The number of market centres in other blocks are more, therefore each market centre serves the area, population and number of villages is less than district average. Fig. 5shows the composite index of rural market centres. 


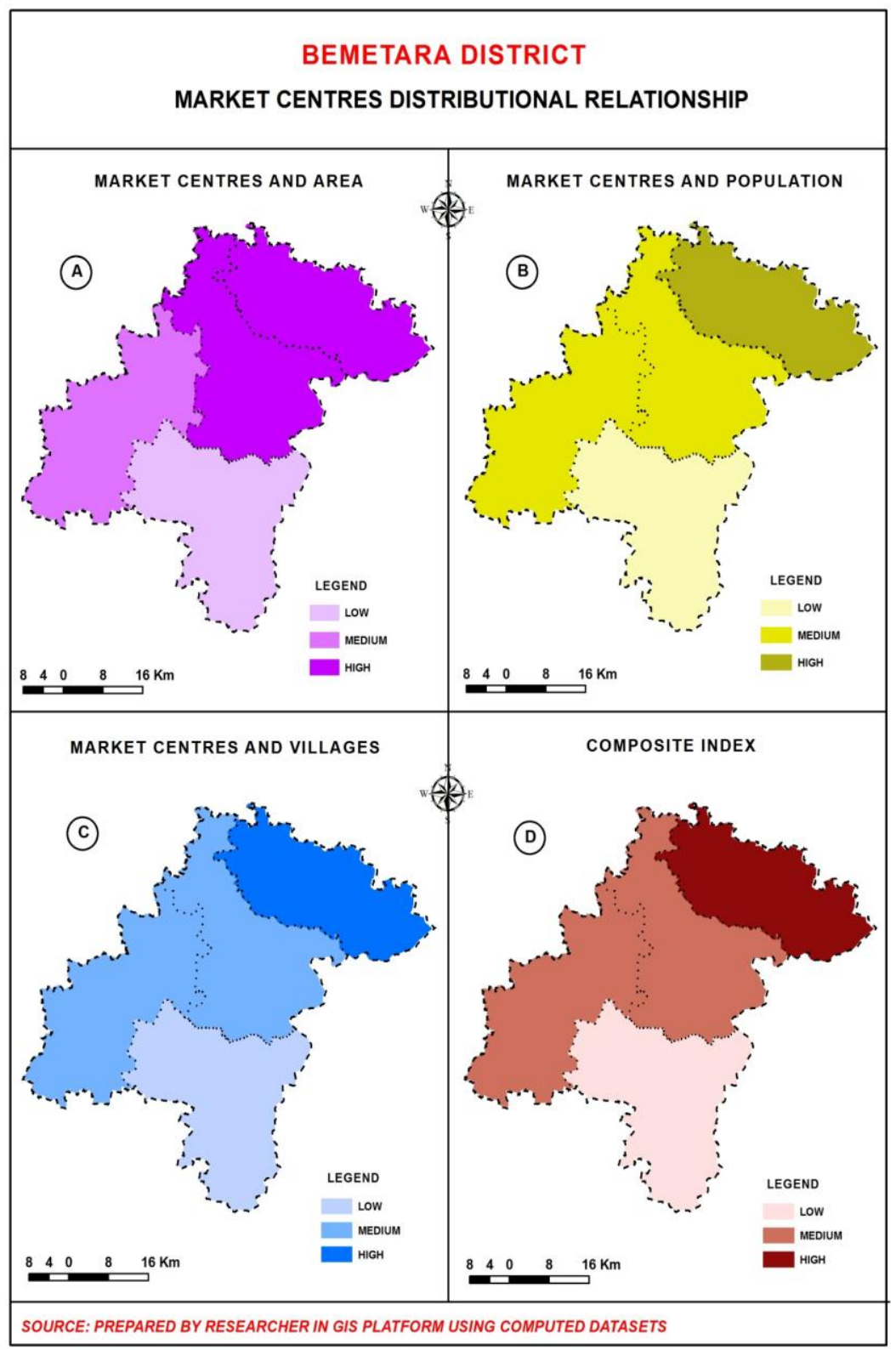

Figure 5 Bemetara District: Market Centres Distributional Relationship

\subsection{Served and Un-Served Area by Rural Weekly Markets}

Market area never functions in isolation as it mainly dependent on the surrounding area. The existence of any rural market centre mainly depends on the rich agricultural hinterland. It defines that, larger the market area greater will be the area of influence. Market is a geographical area from which it draws its customers and offer them retail as well as other services. It has observed that, the villages that comes under the service are of one market centre can also be under the influence of some other market but on different day. The settlement which comes under the influence of more than one market are considered as command area with more beneficiary of the marketing facilities. Those settlements which are lying in the unserved area of influence of markets are making use of retail shops shown in Fig. 6.The study area has 2862.16 sq. km. of total geographical area, out of which $2664.18 \mathrm{sq}$. $\mathrm{km}$ of area is served by 108 rural markets and remaining $198 \mathrm{sq} . \mathrm{km}$. of area is un-served. Therefore it has been found that the measurement of the served and un-served area of the market centres help to find out the poorly served area in Bemetara district, which will get significance for planning and development strategies. 


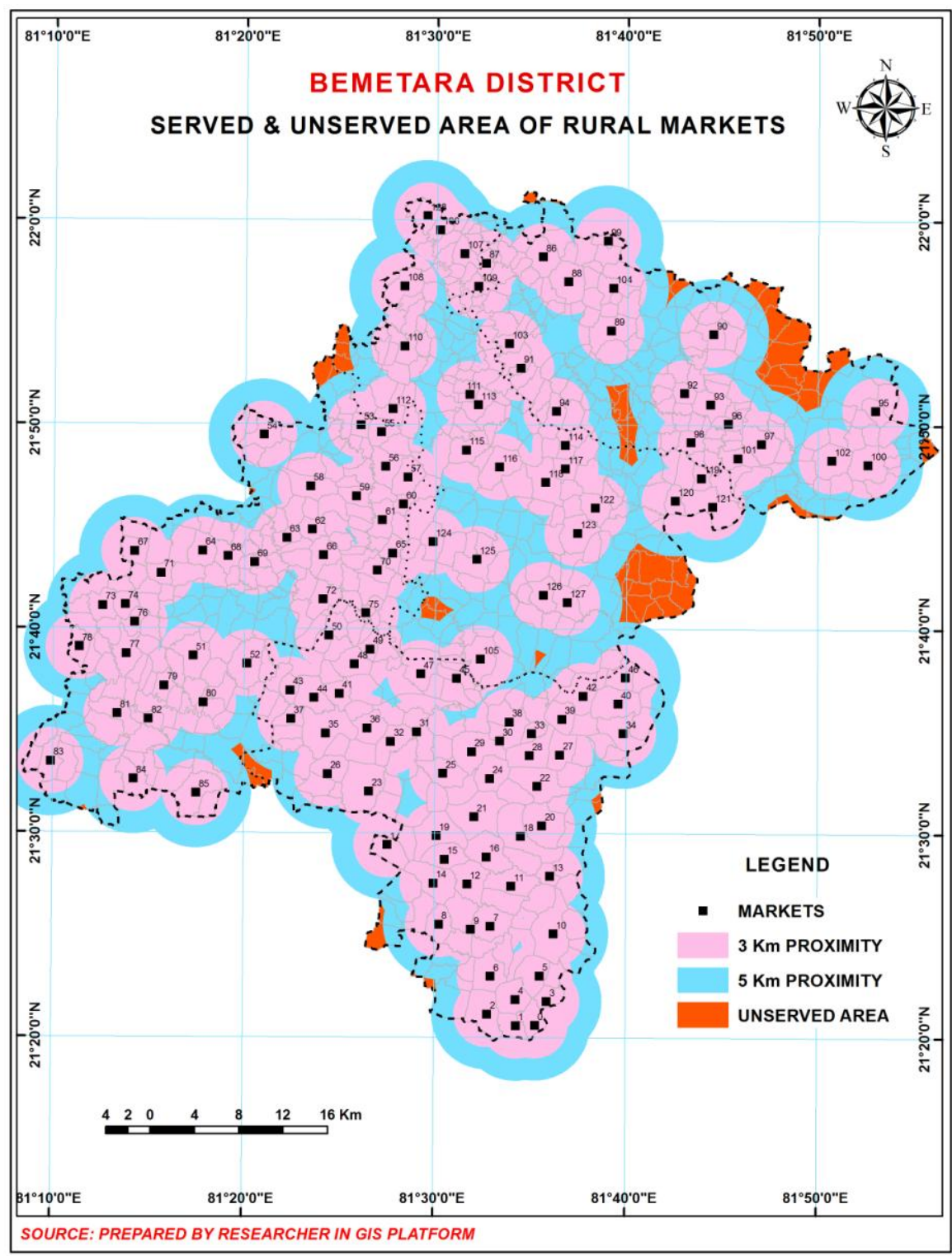

Figure 6 Bemetara District: Served \& Un-served Area of Rural Market

Investigation of rural weekly market functions are very important part of marketing studies mainly to understand the extent of markets for spatial interactions. The significance of the market centre reproduce the number of quality of functions it mainly perform for a area. Therefore, the functions of weekly markets in Bemetara district are considered on the basis of locational characteristics. Generally, these weekly markets are located at the middle of the rural communities or in the very heart of the village in the open space or along access to roads or adjoining the Grampanchayat office or around any religious centre, where buyers and sellers meet at a specific time and at a specific day. It has observed in the study area that, the distinctive characteristics of plain region have paved the approach for coming out of many weekly markets. As a result, the nodal centres and contact zones are responsible for emergence of rural periodic markets with heterogeneity in their functions. All the four blocks including district headquarter, carry out the wholesale and retailing activities in the market attracting both buyers and sellers from the surrounding villages or the instantaneous vicinity of the village. The essential verities of commodities of rural areas are brought for sale in the market. These rural weekly market centres serve as suitable channels for distribution of agricultural and other products and for providing services of artisans and craftsmen. All the 108 rural periodic markets are well served by the different types of mobile traders who brought seasonal commodities. Apart from this, the producer sellers, service sellers and the part time traders uniformly take part in the marketing activities and play their vital role as an important market functionary. The sense of balance between all the market functionaries leads to successful functioning of the rural market centres. 


\section{CONCLUSION}

Markets are considered as key components to formulate the regional development strategies. Hence, an attempt has been made in this research paper to investigate the concentration of rural weekly markets of Bemetara district. Without markets the settlements cannot develop to expected level. Therefore, it is the need of the hour to put forward the spatial planning strategies for further development of market in Bemetara district, where gaps have identified by this research work. Spatial distribution of rural weekly markets is the main observation and is responsible for spatial interaction and rural development. Therefore, concentration has paid to identify the number of settlements served by all the 108 rural weekly markets and also the number of settlements served by more than one weekly market in the study area. GIS and GPS here played an important role in advance study of market geography in geospatial dimension. The calculated value of Rn 1.28 shows that the spatial distribution of markets deviation from random pattern. The periodicity of the market meetings indicated that the Thursday being the highest market meetings are held followed by Monday, Wednesday and Sunday mainly due to the dominance of socio-religious factors in the study area. GIS helps to find out the served and un-served area in the study region for further planning and development purpose. Planners need to be conscious of functioning style of the markets and then only they could design the proper and suitable planning strategy for further development. On the other hand, market development should not be random in nature but also an improved condition resulted in to not only a well-organized management but also useful marketing activities. The gap between served and un-served area has to be reduce and take them in to the fold of served area by proposing new periodic markets from temporal point of view.

\section{ACKNOWLEDGEMENTS}

Authors would like to express gratitude to Chhattisgarh Space Application Centre (CGSAC), Raipur for providing satellite data and GIS lab facility and other basic infrastructures to carry out the research work. Authors are also thankful all other lined departments for providing all hardcopy data related rural market for the study.

\section{REFERENCES}

[1] Dixit, R.S, Spatial Organization of Market Centers in Hamirpur District (Pointer Publisher, Jaipur, 1981).

[2] Wanmali, S, Periodic Markets and Rural Development in India (Contribution to Indian Geography, G.K. Publishing House, Vanaras, 1987).

[3] Hugar, S.I, Traditional and Non-Traditional Market Exchange, A Study in Spatial Development ( G.K. Publishing House, Varanasi, 1982).

[4] Agarwal, P.C. ,Weekly Market Size and Service area in Bastar District, Madhya Pradesh, The Indian Geographical Journal, Vol. 13, 1968.

[5] Deka, N. and Bhagabati, A.K, Periodic Markets in an Agricultural Environment. A Study of Bramhaputra Floodplain, Assam, Geographical Review of India, Vol. 71, No. 4,2009, 412-425.

[6] Saxena, H.M, Marketing Geography (Rawat Publication, Jaipur, 2004).

[7] Mulimani, A.A Marketing Geography. A Spatio-Functional Perspective (Premiere Publication, Dharwad, 2006).

[8] Mulimani, A.A. and Begaum, M.S,Periodic Market and Rural Development. A Case Study of Haveri District, Golden Research Thoughts, Vol. 1, Issue 11, 2012, 1-6.

[9] Mandal, R.B. Introduction to Rural Settlements (Concept Publishing Company, New Delhi, 2001). 